\title{
Top Executives
}

National Cancer Institute

\section{Source}

National Cancer Institute. Top Executives. NCI Thesaurus. Code C122525.

Upper-level managers who devise strategies and policies to ensure that an org anization meets its goals. They plan, direct, and coordinate operational activities of companies and organizations. 